\title{
POTENSI AGENSIA HAYATI DALAM MENEKAN LAJU SERANGAN PENYAKIT BLAS (Pyricularia oryzae) PADA TANAMAN PADI
}

\author{
${ }^{1}$ Dian Eka Kusumawati, ${ }^{2}$ Istiqomah \\ Fakultas Pertanian, Universitas Islam Darul 'Ulum Lamongan \\ Lamongan, Indonesia \\ Email : ${ }^{1}$ dianeka@unisda.ac.id, ${ }^{2}$ istiqomah@unisda.ac.id
}

\begin{abstract}
Blast disease is an important disease that affects many rice plants. Blasts can damage rice leaves (leaf blasts), nodes (node blasts), neck blasts, colar blasts and rice grains. Symptoms on the leaves are rhombic-shaped spots with a tapered tip. The center of the patch is gray surrounded by brown to reddish brown on the edge of the spot. The color of the spots at the beginning of the symptoms is white or gray, surrounded by greenbrown. Based on market demand, agricultural products that are safe and healthy for consumers as well as environmentally friendly are increasing, therefore controlling plant pathogens by using antagonistic microorganisms is one of the ways that must be considered. A number of microbes have been widely tested and are quite effective in controlling plant pathogens. PGPR and Streptomyces are biological agents that are able to reduce the level of attack of plant diseases, especially in rice blast disease. This study used a comparative method between rice cultivation and biological agent applications and rice cultivation without biological agents or control plant applications. The results obtained indicate that the application of biological agents can reduce the percentage of disease severity, reduce the percentage of infected leaves, the biological agents are also able to extend the incubation period, increase plant height growth, number of tillers and also the number of grains per panicle.
\end{abstract}

\section{Keywords: biological agents, PGPR, streptomyces, blast disease}

\section{PENDAHULUAN}

Penyakit blas yang diakibatkan cendawan Pyricularia oryzae merupakan penyakit utama yang banyak menyerang tanaman padi. Di negara-negara di dunia, tingkat penyebaran penyakit blas sudah meluas termasuk di dalam negeri Indonesia. Penyakit blas ini banyak dijumpai pada sentra-sentra produksi padi yang ada (Sudir dkk., 2014). Hampir setiap negara di dunia yang berpotensi menjadikan padi sebagai penghasil pangan utama memiliki data kehilangan hasil produksi dikarenakan penyakit ini. Menurut penelitian dari Wang et al (2014) menyatakan bahwa kerugian dari produksi padi di Jepang ditafsirkan sebesar 20 sampai 100\%; di negara Brasil bahkan bisa sampai 100\%; di Negara India sekitar 5 sampai dengan 10\%; di Korea sebesar 8\%; di China sebesar $14 \%$ dan Filipina mencapai $50-85 \%$. Pada intensitas serangan yang penyakit yang cukup tinggi, kehilangan hasil produksi padi yang diakibatkan oleh penyakit blas yang diakibatkan oleh cendawan ini bisa sampai persentase yang cukup tinggi yaitu $90 \%$. Pada data penelitian Sudir dkk (2014) terdapat area persawahan yang beririgasi terserang penyakit blas ini, di Jawa Timur salah satunya adalah Lamongan (Sudir dkk, 2014). Dari data tersebut bermanfaat untuk pengambilan keputusan bagaimana cara pengendalian yang tepat, diperlukan penelitian-penelitian yang berkaitan dengan pengendalian penyakit tanaman padi, memprediksi produksi padi nasional tiap tahunnya, perlu atau tidaknya melakukan impor (Suganda, 2016). 
Penyakit blas dapat merusak daun padi (leaf blast), pada bagian buku atau biasa disebut node blast, pada bagian leher malai tanaman atau neck blast, kolar daun (colar blast) dan bulir padi. Gejala yang nampak pada daun bisa berupa bercak yang membentuk belah ketupat dengan ujungnya yang meruncing. Bagian tengah pada gejala yang nampak berupa bercak berwarna abu-abu yang disekelilingnya berwarna coklat sampai coklat kemerahan di bagian pinggir bercak. Warna bercak diawal gejala putih atau keabuan yang dikelilingi warna hijau coklat (Novrika, 2019).

Teknik ataupun teknologi pengendalian penyakit yang ada di lapang kebanyakan masyarakat atau petani masih sering menggunakan bahan-bahan kimia yang cukup berbahaya seperti pestisida. Penggunaan pestisida yang tidak tepat jenis dan dosis dapat menimbulkan kerugian ekonomi bagi petani dan juga mengakibatkan racun bagi lingkungan (Djojosumarto, 2008). Masih banyaknya penggunaan pestisida dikarenakan minim pengetahuan tentang pengendalian secara biologi/ramah lingkungan, selain itu dengan menggunakan pestisida dirasa cukup praktis dan cepat memperlihatkan hasil meskipun akan menimbulkan dampak yang negatif. Alternatif pengendalian penyakit pada padi bisa dilakukan dengan cara penerapan sistem pengendalian hayati. System ini sesuai dengan program yang sudah dijalankan oleh pemerintah yang menggunakan system pengendalian hama dan penyakit secara terpadu (Sa'diyah dkk, 2013).

Dalam masa sekarang, permintaan terhadap hasil dari pertanian yang aman dan sehat untuk dikonsumsi konsumen dan juga ramah terhadap lingkungan cukup meningkat di pasaran, oleh sebab itu pengendalian pathogen tanaman dengan menggunakan mikroorganisme antagonis menjadi salah satu cara yang harus dipertimbangkan. Mikroorganisme seperti cendawan dan bakteri sudah banyak teruji dapat memberikan perlawanan terhadap serangan pathogen tanaman (Soesanto, 2008). Agens hayati yangbiasa digunakan adalah mikroba alami yang mempunyai sifat sebagai inhibitor terhadap pertumbuhan patogen serta mampu berkompetisi terhadap patogen dalam hal tempat ataupun nutrisi yang dibutuhkan (Supriadi, 2006). Mekanisme yang terjadi biasanya merupakan antagonis yang bisa berupa lisis, antibiosis, parasite serta persaingan (Winarsih dan Syafrudin, 2001).

Pengendalian hayati dapat diartikan sebagai cara untuk mengatur populasi organisme atau patogen dengan musuh-musuh alam yang ada sehingga populasi patogen tetap berada di bawah ambang rata-rata bila dibandingkan dengan tanpa pengendalian (Purnomo, 2010). Jenis dari agens hayati yang biasa dikembangkan adalah agens hayati yang mempunyai sifat sebagai penghambat pertumbuhan patogen tanaman dan mampu bersaing dalam memperoleh nutrisi (Octriana, 2018). Pengendalian hayati ini merupakan pengendalian yang bersifat aman karena tidak mencemari lingkungan dan juga tidak menimbulkan keracunan bagi manusia dan hewn ternak dan menyebabkan resistensi patogen (Purnomo, 2010).

Menurut penelitian dari Jumar (2000). Pengendalian secara hayati memeliki beberapa keuntungan diantaranya adalah: (1) Lingkungan tidak tercemari mencemari lingkungan dan aman untuk manusia dan hewan ternak konsumsi, (2) tidak terjadi resistensi pada hama maupun penyakit tanaman, (3) Peran antagonis alami mampu bekerja secara efektif terhadap sasarannya, (4) permanen dalam kurun waktu yang cukup panjang, lebih murah bila dibandingkan dengan pengendalian secara kimia. Selain keuntungan pengendalian hayati terdapat juga beberapa kelemahannya, seperti: (1) Sulit memprediksi hasilnya dalam jangka waktu yang singkat, (2) Dibutuhkan penelitian terlebih dahulu sebelum melakukannya, (3) membutuhkan tempat khusus seperti Laboratorium untuk menganalisa lebih dalam, (3) belum banyak diaplikasikan di lapang. 
Pengendalian penyakit blas yang terdapat pada padi ini bisa dengan memanfaatkan agensia hayati untuk menekan laju serangan pathogen dan meningkatkan pertahanan pada tanaman. Terdapat beberapa mikroba yang sudah banyak dilaporkan dari berbagai hasil penelitian efektif sebagai agens hayati pengendali penyakit tanaman, mikroba yang dapat berfungsi untuk menjadi agensia hayati pengendali penyakit tanaman adalah Streptomyces spp. Streptomyces mempunyai kemampuan yang cukup tinggi dalam menghasilkan senyawa bioaktif sebagai penghambat perkembangan patogen (Lestari, 2006). Streptomyces isolat lokal juga dilaporkan mampu menghambat serangan patogen penyebab penyakit layu pada tomat (Sari dkk, 2012) dan cabai (Papuangan, 2009). Pada tanaman kedelai dapat menghambat serangan pathogen Xanthomonas axonopodis (Ifdal 2003 dan Andri 2004). Oleh karena itu pemanfaatan Streptomyces sebagai agens hayati perlu dikembangkan lebih lanjut.

PGPR atau Plant Growth Promoting Rhizobacteria adalah agensia hayati yang kemampuannya sudah banyak dibuktikan oleh para peneliti dalam mengendalikan beberapa pathogen yang menyerang tanaman (Kloepper et al. 2004). PGPR adalah kelompok bakteri rhizosfer yang memiliki kemampuan mengkolonisasi daerah perakaran secara agresif serta memberikan keuntungan bagi tanaman. Beberapa bakteri mempunyai pengaruh yang bermanfaat bagi tanaman sehingga disebut PGPR, yaitu kelompok Bacillus sp., dan Pseudomonas sp. (Kumar dkk, 2011).

Penelitian tentang penggunaan agens hayati untuk menekan serangan penyakit telah banyak dilakukan, namun masih menunjukkan presentase penekanan yang rendah (di bawah 50\%). Hal ini diduga karena penggunaan agens hayati dilakukan hanya pada fase tertentu saja dalam pertumbuhan padi. Pengoptimalan pengendalian hayati perlu dilakukan secara sistematis mulai dari fase pengolahan tanah, persemaian, pemupukan, hingga penyemprotan selama masa vegetatif.

\section{BAHAN DAN METODE}

Pelaksanaan penelitian ini bertempat di Desa Mojolebak, Kembangbahu, Lamongan. Areal sawah yang digunakan penelitian ini berada pada ketinggian 8 mdpl dengan sistem sawah irigasi. Penelitian dilakukan bulan Mei sampai dengan bulan Juli 2020. Adapun alat yang digunakan atau diperlukan adalah traktor, alat penyemprot, pipa irigasi, terpal, tong plastic, timbangan manual, timbangan analitik, cangkul, dan kamera. Untuk bahan yang digunakan pada penelitian ini adalah benih padi varietas Inpari, pupuk petroganik, pupuk Urea, TSP, agens hayati Streptomyces sp., Plant Growth Promoting Rhizobacterium (PGPR) yeng mengandung Pseudomonas fluorescens dan Bacillus subtiluis.

\section{Metode percobaan}

Lahan penelitian yang digunakan terdiri dari 10 petak perlakuan dengan aplikasi agens hayati dan 10 petak untuk kontrol. Satu petak berukuran $4 \mathrm{~m} 2$ dengan menggunakan jarak tanam selebar $20 \mathrm{~cm}$ x $20 \mathrm{~cm}$.

\section{Perlakuan Agens Hayati}

Perlakuan dengan agens hayati Padi yang akan disemai direndam PGPR dengan konsentrasi $10 \mathrm{ml} / \mathrm{L}$ selama 8 jam kemudian ditiriskan dan dilakukan pemeraman selama 1 x 24 jam hingga berkecambah. Saat persemaian berumur 5 hari dan 8 hari dilakukan penyemprotan PGPR dengan konsentrasi $20 \mathrm{ml} / \mathrm{L}$ untuk memacu pertumbuhan persemaian padi. Saat persemaian berumur 7 HSS dilakukan pemupukan urea dan dilakukan penyemprotan insektisida. Pemindahan padi ke sawah saat dilakukan saat padi 
berumur 16 HSS (Hari Setelah Semai). Pemupukan berdasarkan perhitungan rekomendasi yaitu pupuk urea $300 \mathrm{~kg} / \mathrm{ha}$, pupuk TSP $50 \mathrm{~kg} / \mathrm{ha}$. Pengendalian hama dengan insektisida. Dilakukan penyemprotan agens hayati Streptomyces sp 1 minggu sekali hingga padi berumur 60 HST.

\section{Perlakuan kontrol}

Benih direndam dengan air selama 24 jam kemudian dilakukan pemeraman selama 24 jam. Saat persemaian berumur 7 HSS dilakukan pemupukan urea dan dilakukan penyemprotan insektisida. Bibit yang akan ditanam pada lahan konvensional berumur 25 HSS. Pemupukan dilakukan sesuai dengan kebiasaan petani yang dilakukan di lahan sekitar tempat penelitian. Pengendalian hama menggunakan insektisida, pengendalian penyakit menggunakan fungisida dan bakterisida. Jika muncul gejala penyakit, dilakukan penyemprotan fungisida dan bakterisida dengan interval 1 minggu sekali.

\section{Pengamatan}

Pengamatan meliputi:

1. Tinggi tanaman, pengukuran dilakukan dari pangkal batang tanaman sampai daun tanaman tertinggi.

2. Jumlah anakan per rumpun dapat dihitung berdasarkan jumlah dari anakan tanaman yang sudah terbentuk dalam rumpun.

3. Masa inkubasi penyakit, dihitung dari mulai hari setelah adanya inokulasi atau patogen mulai menyerang sampai muncul gejala.

4. Persentase daun tanaman yang terserang

Pengamatan pada daun yang mengalami serangan penyakit ini dimulai pada saat awal daun terserang sampai dengan daun menimbulkan bercak yang menggunakan rumus (Hakkar et al., 2014) sebagai berikut:

$\mathrm{P}=\boldsymbol{a} / \boldsymbol{b} \times 100 \%$

Ket:

$\mathrm{P}=$ Persentase daun yang terserang

$\mathrm{a}=$ Jumlah daun tanaman yang menunjukkan gejala serangan

$\mathrm{b}=$ Jumlah daun yang kita diamati

5. Keparahan serangan penyakit, pengamatan kejadian penyakit utama pada padi dilakukan pada jumlah tanaman yang terserang dan menunjukkan gejala penyakit. Pengamatan kejadian penyakit dilakukan seminggu sekali, akan tetapi data yang digunakan untuk dianalisis merupakan data pada pengamatan minggu terakhir. Perhitungan intensitas penyakit mengunakan rumus menurut Arwiyanto et al (2007):

Ket:

$\mathrm{KP}$ : Persentase kejadian penyakit (\%), $\mathrm{n}$ : Tanaman yang terserang, $\mathrm{N}$ : Total seluruh tanaman $(\mathrm{cm})$

6. Jumlah gabah per malai diamati dengan perhitungan manual.

\section{Analisis Data}

Analisis data yang didapatkan dari hasil penelitian diuji dengan menggunakan uji $\mathrm{t}$ dengan tingkat ketelitian 95\%. 


\section{HASIL DAN PEMBAHASAN}

\section{Gejala Penyakit Blas (Pyricularia oryzae)}

Penyakit blas dikenal sebagai penyakit yang cukup penting atau penyakit utama pada tanaman padi, penyebabnya adalah cendawan Pyricularia oryzae. Gejala yang ditimbulkan penyakit ini (Gambar 1) adalah adanya bercak pada daun yang membentuk seperti belah ketupat dengan ujung yang meruncing. Pada bagian tengah bercak berwarna seperti abu-abu yang disekelilingnya berwarna coklat. Hal ini sejalan dengan pendapat Novrika (2009) yang menyebutkan warna bercak diawal gejala berwarna putih atau keabuan yang dikelilingi warna hijau coklat

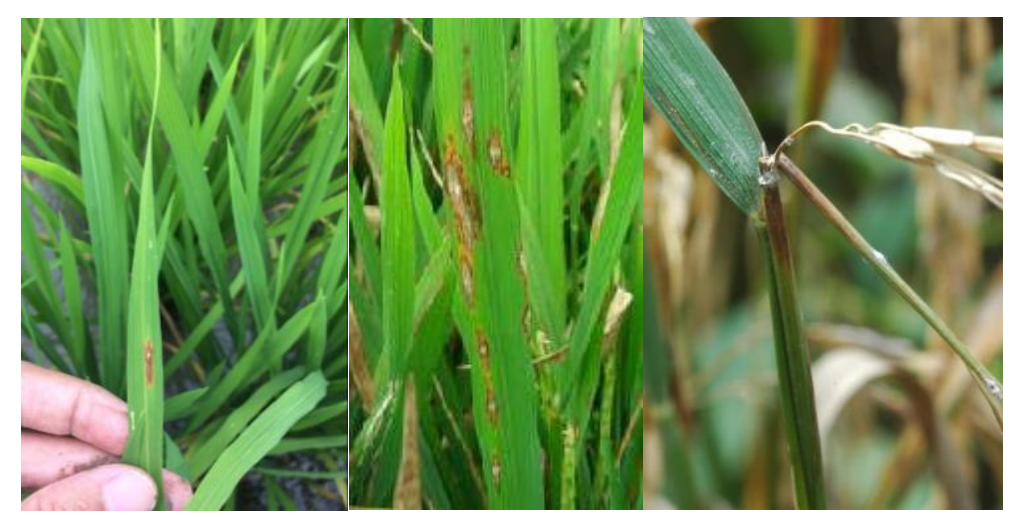

Gambar 1. Gejala Penyakit Blas

Pada umumnya penyakit blas ini menyerang daun dan juga leher malai pada tanaman padi yang disebut blas daun dan blas leher. Perkembangan penyakit blas ini menunjukkan bentuk yang khas yaitu elips dan ujungnya runcing seperti belah ketupat. Bercak ini diawali dengan bercak kecil berwarna hijau kemudian berkembang membesar berwarna kecoklatan pada tanaman yang rentan atau peka terutama pada keadaan yang lembab. Bercak mampu berkembang sampai 1-1,5 cm dengan lebar bercak sebesar 0,3$0,5 \mathrm{~cm}$ pada daun tanaman dan pada tepi bercak berwarna coklat. Bercak daun pada tanaman yang rentan tidak begitu jelas pembatas tepinya dan dikelilingi warna kuning pucat terutama pada keadaan lembab, sulit untuk diperjelas. Pada tanaman yang tahan, bercak tidak akan berkembang menjadi lebar. Pada tanaman yang sedang akan menunjukkan bercak berbentuk bulat atau elips dengan tepi kecoklatan yang berkembang beberapa millimeter saja kemudian menunjukkan interaksi yang sedang. Untuk blas leher menunjukkan gejala busuk berwarna coklat keabuan pada pangkal malai sehingga mengakibatkan malai patah dan gabah tidak berisi.

Menurut Santoso dan Anggiani (2008) faktor utama yang memengaruhi persebaran penyakit blas ini baik adalah kelembaban. Penyakit blas ini mampu berkembang secara optimal pada suhu 24-28 derajat Celsius dengan kelembaban udara yang mencapai $90 \%$ (IRRI, 2010). Faktor lain yang mempengaruhi perkembangan penyakit blas ini adalah angin karena angin dapat membantu penyebaran spora penyakit blas dengan cepat dan jarak yang ditempuh cukup jauh yaitu sekitar sampai $2 \mathrm{~km}$. Kurangnya air juga menjadi faktor penentu perkembangan penyakit blas ini, banyak penelitian yang menyebutkan penanaman padi di lahan kering dapat memicu serangan penyakit blas yang cukup parah, hal ini diduga karena kandungan silisum pada lahan kering berkurang sehingga membuat tanaman menjadi rentan akan penyakit. Penyakit blas ini juga dapat memnfaatkan gulma yang ada di sekitar lahan budidaya sebagai inang alternatif (Hidayat, 2012). 


\section{Tinggi Tanaman}

Dari hasil pengamatan yang dilakukan pada Tabel 1 diketahui bahwa hasil uji-t rerata tinggi tanaman padi umur 90 hst pada perlakuan agens hayati menunjukkan hasil lebih tinggi atau hasil yang lebih baik jika dibandingkan dengan kontrol. Pada petak perlakuan dengan menggunakan agens hayati rerata tinggi tanaman sebesar $98,7 \mathrm{~cm}$. Sedangkan pada perlakuan kontrol sebesar $81,9 \mathrm{~cm}$ yang menunjukkan adanya perbedaan nyata $(\mathrm{p}=0,00)$

Tabel 1. Rerata Tinggi Tanaman Padi $(\mathrm{cm})$

\begin{tabular}{lc}
\hline \multirow{2}{*}{ Perlakuan } & Rerata Tinggi Tanaman Padi 90 hst $(\mathrm{cm})$ \\
\cline { 2 - 2 } & $\mathrm{x} \pm \mathrm{SD}$ \\
\hline Agens Hayati & $98,7 \pm 3,05$ \\
Kontrol & $81,9 \pm 6,4$ \\
\hline $\mathrm{p}$ & 0,00 \\
\hline
\end{tabular}

\section{Pertumbuhan Tinggi Tanaman}

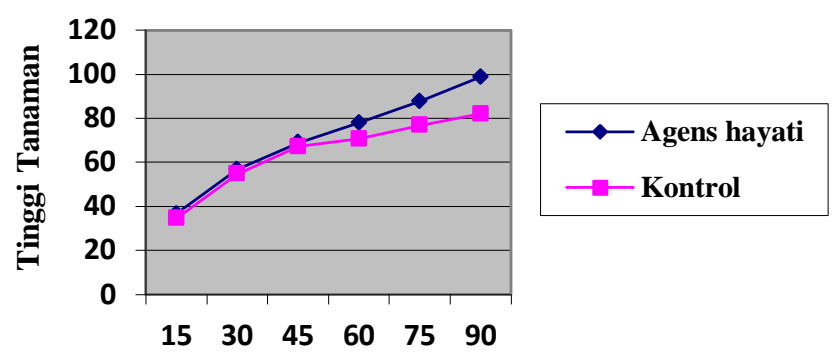

Lama Hari Setelah Tanam

Gambar 2. Pertumbuhan Tinggi Tanaman Padi

Pada Gambar 2 menunjukkan grafik pertumbuhan tinggi tanaman padi pada perlakuan agens hayati dan perlakuan kontrol pada umur 15 hst, 30 hst, 45 hst, 60 hst, 75 hst dan 90 hst. Hasil yang didapatkan adalah tinggi tanaman pada agens hayati menunjukkan bahwa hasilnya nyata lebih baik jika dibandingkan dengan tanaman kontrol pada umur 60 hst, 75 hst sampai dengan 90 hst.

Pengaplikasian agens hayati mendapatkan hasil yang lebih tinggi pada pertumbuhan tanaman khususnya pada tinggi tanaman dibandingkan dengan tanaman kontrol yang tanpa aplikasi agens hayati. Hal ini dikarenakan pengaplikasian agens hayati pada budidaya tanaman padi dapat meningkatkan pertumbuhan tanaman dengan kandungan-kandungan yang ada di dalamnya sehingga mampu mengoptimalkan pertumbuhan tanaman. Sependapat dengan Yuen \& Schroth (1986) yang berpendapat bahwa adanya bakteri yang terdapat dalam PGPR dapat meningkatkan pertumbuhan dan perkembangan tanaman, mampu memicu tumbuh kembangnya tanaman padi yang cukup erat kaitannya dengan beberapa hormone yang dihasilkan. Adapun beberapa hormone tumbuh yang dihasilkan adalah IAA, auksin, giberelin, sitokinin dan etilen (Karnwal. 2009). Selain itu kemampuan PGPR adalah dapat memfiksasi kandungan N, melarutkan fosfat (Faccini et al. 2004) serta mendegradasi dan dapat memanfaatkan sebagian besar senyawa organik ataupun senyawa anorganik yang ada dalam tanah dan juga mekanisme dalam peningkatan pertumbuhan tanaman juga disebabkan oleh adanya fitohormon yang dihasilkan oleh Streptomyces. 
Pertumbuhan pada tanaman pada umumnya dapat dipengaruhi oleh adanya zat pengatur tumbuh yang sudah ada dalam jaringan pada tanaman, zat ini mampu mengkoordinasi terjadinya proses fisiologi yang ada pada yang mampu mengkoordinasi terjadinya proses fisiologi yang ada pada tubuh tanaman, proses tersebut Antara lain terjadinya pembesaran pada sel, terjadinyan diferensiasi pada jaringan tanaman, adanya respon tanaman terhadap sinar cahaya dan terhadap gravitasi yang ada (Teale et al. 2006). Zat pengatur tumbuh ini selain dirpoduksi oleh tanaman juga diproduksi oleh beberapa senyawa yang terkandung dalam agens hayati yang mampu menghasilkan indole acetic acid atau IAA yang secara umum dapat meningkatkan pertumbuhan dan perkembangan hasil.

\section{Jumlah Anakan}

Tabel 2. Rerata Jumlah Anakan Per Rumpun

\begin{tabular}{lc}
\hline \multirow{2}{*}{ Perlakuan } & Rerata Jumlah Anakan per Rumpun \\
\cline { 2 - 3 } & $\mathrm{x} \pm \mathrm{SD}$ \\
\hline Agens Hayati & $22,3 \pm 1,7$ \\
Kontrol & $20,3 \pm 1,8$ \\
\hline $\mathrm{p}$ & 0,02 \\
\hline
\end{tabular}

Berdasarkan data hasil pengujian rerata jumlah anakan pada Tabel 2 didapatkan hasil signifikan $(\mathrm{p}=0,02)$ antara perlakuan menggunakan agens hayati dan perlakuan kontrol. Didapatkan rerata jumlah anakan pada perlakuan agens hayati sebesar 22,3 yang menunjukkan hasil lebih banyak jika dibandingkan dengan rerata jumlah anakan pada perlakuan non agens hayati atau kontrol yaitu sebesar 20,3. Pengaplikasian agens hayati PGPR yang dilakukan mulai dari perlakuan benih padi sampai dengan penyemaian dan penyemprotan pada tanaman dari fase vegetative sampai generative padi dapat menaikkan hasil pertumbuhan dan juga hasil produksi tanaman. Pertumbuhan tanaman dapat meningkat karena adanya interaksi atau hubungan yang menguntungkan diantar PGPR dan tanaman. PGPR membutuhkan senyawa metabolit untuk sumber nutrisinya dengan cara mengkoloni akar tanaman. Bakteri yang terdapat dalam PGPR dapat menghasilkan zat yang mengatur pertumbuhan tanaman dan dapat menginduksi perakaran dalam tanaman sehingga tanaman mampuh bertumbuh secara optimal. Adanya system perakaran tanaman yang baik akan meningkatkan daya serap akar terhadap nutisi-nutrisi yang ada. Keadaan seperti ini menjadi factor penyebab jumlah anakan yang produktif dan hasil yang lebih tinggi.

Menurut Kilian et al (2000) Pengaplikasian senyawa yang mengandung Bacillus subtilis mampu meningkatkan tingi tanaman, meningkatkan jumlah anakan dan juga hasil panen. Yang mana dapat memperbaiki perakaran tanaman melalui perlakuan benih dan pencelupan akar tanaman. Vasudevan et al (2002) juga melaporkan bahwa senyawa tersebut mampu meningkatkan panjang akar, panjang tunas, dan menghasilkan produksi panen yang cukup tinggi dibandingkan dengan kontrol. 
Masa Inkubasi

Tabel 3. Rerata Masa Inkubasi

\begin{tabular}{lc}
\hline \multirow{2}{*}{ Perlakuan } & Rerata Masa Inkubasi (hari) \\
\cline { 2 - 2 } & $\mathrm{x} \pm \mathrm{SD}$ \\
\hline Agens Hayati & $3,3 \pm 0,6$ \\
Kontrol & $2,7 \pm 0,6$ \\
\hline $\mathrm{p}$ & 0,06 \\
\hline
\end{tabular}

Masa inkubasi merupakan waktu setelah patogen menyerang tanaman sampai menimbulkan gejala. Pada Tabel 3 memperlihatkan rerata masa inkubasi penyakit blas pada tanaman padi, didapatkan data yang tidak signifikan $(\mathrm{p}=0,06)$ antara perlakuan agens hayati dan kontrol. Rerata masa inkubasi yang didapat pada perlakuan agens hayati sebesar 3,3 hari, hal ini lebih lama dibandingkan dengan rerata masa inkubasi pada kontrol yaitu sebesar 2,7 hari. Meskipun tidak menunjukkan hasil yang signifikan tetapi perlakuan dengan menggunakan agens hayati mampu memperpanjang masa inkubasi penyakit blas pada tanaman padi dibandingkan dengan perlakuan kontrol yang mempunyai masa inkubasi yang lebih singkat.

Menurut Saragih (2009) kandungan mikoriza yang terdapat pada agens hayati mempunyai peran dalam upaya meningkatkan kesehatan tanaman dan juga mampu mengendalikan patogen tanaman atau dengan kata lain meningkatkan ketahanan sistemik yang ada dalam tanaman. Tanaman dengan pengaplikasian agens hayati mampu bertahan dari serangan pathogen tanaman khususnya pathogen yang ada di akar tanaman. Selain meningkatkan ketahanan sistemik juga dapat menciptakan lingkungan yang cukup baik untuk pertumbuhan tanaman dalam upaya penyerapan karbohidrat dan eksudat yang ada pada akar tanaman sehingga mengurangi perkembangan serangan pathogen.

\section{Persentase Daun Terserang}

Hasil analisis uji-t pada rerata persentase daun terserang menunjukkan data yang berbeda nyata atau signifikan $(\mathrm{p}=0,00)$ antara perlakuan dengan menggunakan agens hayati dan perlakuan kontrol atau perlakuan tanpa agens hayati. Pada Tabel 4 dapat dilihat hasil rerata persentase daun terserang pada perlakuan agens hayati menunjukkan hasil sebesar 32,9\% sedangkan pada perlakuan kontrol yaitu sebesar $42 \%$

Tabel 4. Rerata Persentase Daun Terserang

\begin{tabular}{lc}
\hline \multirow{2}{*}{ Perlakuan } & Rerata persentase daun terserang \\
\cline { 2 - 2 } & $\mathrm{x} \pm \mathrm{SD}$ \\
\hline Agens Hayati & $32,9 \pm 4,5$ \\
Kontrol & $42 \pm 4,6$ \\
\hline $\mathrm{p}$ & 0,00 \\
\hline
\end{tabular}

Data di atas menunjukkan adanya perbedaan nyata antara rerata persentase daun terserang perlakuan agens hayati dengan kontrol. Rerata presentase daun terserang pada perlakuan kontrol lebih tinggi dibandigkan dengan rerata persentase perlakuan agens hayati. Hal ini dikarenakan pada pengaplikasian agens hayati terdapat banyak senyawa yang mampu menghambat perkembangan penyakit blas sehingga mampu menekan gejala penyakit yang muncul pada tanaman. Seperti halnya pendapat Lestari (2006) bahwa Streptomyces yang digunakan sebagai agens hayati mempunyai kemampuan yang cukup tinggi untuk memproduksi senyawa yang bioaktif dan berpotensi sebagai penghambat pertumbuhan dan perkembangan patogen. Selain kandungan yang terdapat dalam 
Streptomyces, kandungan yang ada di dalam PGPR juga mampu menghambat laju patogen tanaman. Sama halnya dengan yang telah dikemukakan Kloepper et al. (2004) bahwa PGPR termasuk salah satu dari sekian agens hayati yang ada yang sudah teruji dalam pengendalian penyebaran penyakit tanaman yang disebabkan oleh pathogen.

\section{Keparahan Penyakit}

Tabel 5.Rerata Persentase Keparahan Penyakit

\begin{tabular}{lc}
\hline & Rerata Persentase Keparahan Penyakit \\
\cline { 2 - 2 } Perlakuan & $\mathrm{x} \pm \mathrm{SD}$ \\
\hline Agens Hayati & $20,2 \pm 1,5$ \\
Kontrol & $33,5 \pm 5,3$ \\
\hline $\mathrm{p}$ & 0,00 \\
\hline
\end{tabular}

Berdasarkan data pada Tabel 4 didapatkan hasil yang nyata atau signifikan $(\mathrm{p}=$ $0,00)$ antara kedua perlakuan. Pada perlakuan agens hayati didapatkan persentase keparahan penyakit sebesar 20,2\% sedangkan pada perlakuan kontrol persentasenya lebih tinggi yaitu sebesar $33,5 \%$. Hal ini menunjukkan penggunaan agens hayati PGPR dan Streptomyces mampu menekan persentase keparahan penyakit blas pada tanaman padi.

Hal ini sependapat dengan pendapat Kloepper et al. 2004 yang menyatakan PGPR termasuk agens hayati yang dapat mengendalikan berbagai patogen tanaman salah satunya penyakit blas pada tanaman padi, begitu juga dengan Streptomyces yang dirasa mempunyai kemampuan cukup tinggi untuk memproduksi senyawa yang bioaktif dan berpotensi dalam penghambatan perkembangan patogen (Lestari, 2006). Kedua agens hayati tersebut juga dapat meningkatkan ketahanan yang terdapat dalam tanaman yaitu ketahanan sistemik yang mampu melawan perkembangan atau persebaran penyakit tanaman yang diakibatkan oleh pathogen tanaman (Compant et al, 2005).

Kemampuan senyawa-senyawa yang terdapat dalam agens hayati mampu mengendalikan penyakit blas pada tanaman padi melalui perlakuan pencelupan benih dan juga penyemprotan tanaman yang dilakukan secara berkala. Perlakuan pencelupan benih dan juga pencelupan akar bibit tanaman pada agens hayati merupakan strategi awal yang dapat menentukan optimal atau tidaknya agens hayati dalam bekerja. Melihat data yang ada pada Tabel 5 menunjukkan pengaplikasian agens hayati PGPR dan Streptomyces mampu menekan perkembangan patogen tanaman. Hal tersebut sependapat dengan Kilian et al. (2000) yang mengemukakan bahwa senyawa yang ada dalam agens hayati dapat bertahan kemudian dapat berasosiasi dan dapat pula berkembang dalam perakaran tanaman sehingga mampu bersaing dan menekan persebaan serangan pathogen. Aplikasi agens hayati juga diduga mampu meningkatkan ketahanan sistemik yang ada pada tubuh tanaman sehingga mampu melakukan perlawanan pada patogen tanaman. Sama halnya dengan pendapat Rahmawaty et al., (2015) yang menyatakan keparahan penyakit tanaman berhubungan dengan sifat yang ada dalam tanaman itu sendiri yaitu sifat ketahanan yang sudah ada dalam tubuh tanaman yang mampu menahan suatu serangan patogen tanaman. Tingkat keparahan serangan penyakit tanaman dapat menimbulkan dampak yang tidak baik untuk pertumbuhan tanaman dan juga hasil produksi tanaman. Untuk tanaman yang menunjukkan gejala serangan penyakit ringan kemungkinan masih ada harapan untuk dapat berproduksi meskipun hasilnya kurang optimal, sedangkan tanaman dengan keparahan penyakit yang cukup tinggi bias menyebabkan gagal panen atau puso.

Kondisi lingkungan yang ada, pada lingkungan biotik ataupun pada lingkungan abiotik juga dapat menimbulkan pengaruh dalam perkembangan penyebaran penyakit yang terjadi di lapangan. Pada kondisi tertentu tanaman bisa saja mengalami serangan 
penyakit yang rendah, namun bisa jadi pada kondisi atau fase berikutnya mengalami persebaran penyakit yang cukup tinggi. Oleh sebab itu pengendalian penyakit sebaiknya dilakukan sedini mungkin mulai perlakuan benih, perlakuan bibit dan juga pengaplikasian agens hayati untuk menekan laju serangan patogen.

\section{Jumlah Gabah Permalai}

Tabel 6. Rerata Jumlah Gabah Permalai

\begin{tabular}{lc}
\hline & Rerata Jumlah Gabah Permalai \\
\cline { 2 - 2 } Perlakuan & $\mathrm{x} \pm \mathrm{SD}$ \\
\hline Agens Hayati & $143,4 \pm 6,2$ \\
Kontrol & $134,1 \pm 4,8$ \\
\hline $\mathrm{p}$ & 0,02 \\
\hline
\end{tabular}

Berdasarkan data hasil uji pada Tabel 6 yang menunjukkan rerata jumlah gabah permalai menunjukkan hasil yang signifikan $(\mathrm{p}=0,02)$ atau berbeda nyata. Pada perlakuan dengan menggunakan agens hayati didapatkan rerata jumlah gabah permalai sebesar 143,4 sedangkan pada kontrol didapatkan rerata yang lebih sedikit yaitu sebesar 134,1. Hal ini dikarenakan pengaplikasian agens hayati pada tanaman padi mampu meningkatkan produksi tanaman dan menekan serangan patogen tanaman.

Menurut Kilian et al (2000) pengaplikasian senyawa yang terkandung dalam agens hayati dapat meningkatkan hasil pertumbuhan tanaman dan juga produktivitas tanaman. Dengan melalui perlakuan pada benih, bibit dan juga penyemprotan agens hayati yang dilakukan secara bertahap mampu mengoptimalkan zat pengatur tumbuh yang ada dalam tanaman sehingga menghasilkan produktivitas yang lebih tinggi. Perlakuan dengan agens hayati juga mampu menekan laju infeksi penyakit dan meningkatkan ketahanan sistemik melalui kandungan senyawa yang terdapat di dalam tubuh tanaman sehingga tanaman dapat tumbuh secara optimal.

\section{KESIMPULAN}

Perlakuan dengan menggunakan agens hayati PGPR dan Streptomyces spp. yang diaplikasikan pada tanaman padi menunjukkan hasil yang efektif dalam menekan persentase keparahan penyakit blas, menekan persentase daun yang terserang, selain itu juga mampu memperpanjang masa inkubasi, meningkatkan tinggi tanaman, serta meningkatkan jumlah anakan tanaman padi per rumpunnya dan juga jumlah gabah pada tiap malainya.

\section{UCAPAN TERIMA KASIH}

Ucapan terima kasih dari penulis disampaikan kepada Kementerian Riset dan Teknologi Republik Indonesia untuk dukungan dana yang telah diberikan melalui program Penelitian Dosen Pemula (PDP) tahun anggaran 2020, dan kepada LPPM Universitas Islam Darul 'ulum Lamongan yang telah memediasi dan memberikan dukungan dan fasilitas penuh sehingga penelitian ini dapat terlaksana dengan lancer dan baik.

\section{DAFTAR PUSTAKA}

A. Kumar, A. Prakash, and B. N. Johri, "Bacillus as PGPR in crop ecosystem," in Bacteria in agrobiology: crop ecosystems, Springer, 2011, pp. 37-59.

Andri C. 2004. Kajian potensi Streptomyces sp. PS1-4 sebagai penghasil senyawa bioaktif pengendali bakteri pathogen tanaman kedelai [skripsi]. Bogor: Fakultas Matematika dan Ilmu Pengetahuan Alam, Institut Pertanian Bogor. 
Arwiyanto T, Asfanudin R, Wibowo A, Martoredjo T, Dalmadiyo G, 2007. Penggunaan Bacillus isolate local untuk menekan penyakit lincat tembakau Temanggung. Berkala Penelitian Hayati 13: 79-84

Compant S, Duffy B, Nowak J, Clement C, Barka EA. 2005. Use of plant growthpromoting bacteria for biocontrol of plant diseases: principles, mechanisms of action, and future prospects. Appl Environ Microbiol 71 (9): 4951-4959.

Faccini G, Garzon S, Martines M, Varela A. 2004. Evaluation of the effects of a dual inoculum of phosphate-solubilizing bacteria and Azotobacter chroococcum, in creolo potato (Papa "Criolla") (Solanum phureya) var 'Yema de Huevo'. www.ag.auburn.edu/ argentina/pdf.manuscripts/ faccini.pdf. Diakses tanggal 28 Desember 2012.

Hakkar, A.A., R. Ade dan M.D. Rahim. 2014. Pengendalian Penyakit busuk buah kakao Phytophthora palmivora dengan cendawan endofit Trichoderma asperllum. Jurnal Pitopatologi Indonesia. 10: 139-144.

Hidayat, I. 2012. Penyakit Blas (Pyricularia oryzae Cav.) pada Tanaman Padi dan Pengandaliannya. BPTP. Kepulauan Bangka Belitung.

I. H. Purnomo and M. Si, Pengantar Pengendalian Hayati. Penerbit Andi, 2010.

Ifdal. 2003. Interaksi antara Streptomyces sp. dengan Bacillus subtilis, Xanthomonas campestris pv glycine, Rhizobia dan Pseudomonas sp. [skripsi]. Bogor: Fakultas Matematika dan Ilmu Pengetahuan Alam, Institut Pertanian Bogor.

IRRI. 2010. Rice Blast. Rice Science for a Better World. Diunduh dari http://www. knoledgebank.irri.org/ tanggal 11 Nopember 2013.

Jumar. 2000. Entomologi Pertanian. Rineka Cipta. Jakarta.

Karnwal A. 2009. Production of indole acetic acid by fluorescent Pseudomonas in the presence of L-tryptophan and rice root exudates. J Plant Pathol 91: 61-63.

Kilian, U., B. Steiner, H. Krebs, G. Junge, Schmiedeknecht, and R. Hain. 2000. FZB24 Bacillus subtilis - mode of action of a microbial agent enhancing plant vitality. PflSchutz-Nachr, Bayer 111: 583-597.

Kloepper JW, Ryu CM, Zhang S. 2004. Induced systemic resistance and promotion of plant growth by Bacillus spp. Phytopathology 94: 1259- 1266.

L. Octriana, "Potensi agen hayati dalam menghambat pertumbuhan Phytium sp. secara in vitro," 2018. Lestari Y. 2006. Identification of indigenous Streptomyces spp. producing antibacterial compound. J Mikrobiol Indones 11(2):99-101.

M. Novrika, "Uji Efikasi Biofungisida Bahan Aktif Trichoderma harzianum Terhadap Penyakit Blas (Phyricularia oryzae) pada Tanaman Padi di Lapangan,” 2019.

Mehrvraz S, Chaichi MR. 2008. Effect of phosphate solubilizing microorganisms and phosphorus chemical fertilizer on forage and garin quality of barley. AmericanEurasian J Agric Environ Sci 3 (6): 855-860.

N. A. Sa'diyah, K. I. Purwani, and L. Wijayanti, "Pengaruh Ekstrak Daun Bintaro (Cerbera odollam) terhadap Perkembangan Ulat Grayak (Spodoptera litura F.)," J. Sains Jadwal penelitian disusun dengan mengisi langsung tabel berikut dengan memperbolehkan penambahan baris sesuai banyaknya kegiatan. Daftar pustaka disusun dan ditulis berdasarkan sistem nomor sesuai dengan urutan pengutipan. 
Hanya pustaka yang disitasi pada usulan penelitian yang dicantumkan dalam Daftar Pustaka. dan Seni ITS, vol. 2, no. 2, pp. E111-E115, 2013.

N. M. Sari, R. KAWURI, and K. KHALIMI, "Streptomyces sp. sebagai biofungisida patogen Fusarium oxysporum (schlecht.) f. sp. lycopersici (sacc.) snyd. et hans. penyebab penyakit layu pada tanaman tomat (Solanum lycopersicum 1.)," Agrotrop J. Agric. Sci., vol. 2, no. 2, 2012.

N. Papuangan, “Aktivitas Penghambatan Senyawa Antimikroba Streptomyces spp. Terhadap Mikroba

Patogen Tular Tanah Secara In Vitro dan In Planta.” Tesis. IPB. Bogor. hal: 22, 2009.

P. Djojosumarto, Panduan Lengkap Pestisida \& Aplikasinya. Agromedia, 2008.

Rahmawaty, Y. S. Sulandari dan S. Hartono. 2015. Respons lima varietas padi terhadap infeksi virus penyebab penyakit kerdil rumput (Rice Grassy Stunt Virus). PROSSEMNAS MASY BIODIV INDON.1(5): 1123-1126

S. Sudir, A. Nasution, S. Santoso, and B. Nuryanto, "Penyakit blas Pyricularia grisea pada tanaman padi dan strategi pengendaliannya," Iptek Tanam. Pangan, vol. 9, no. $2,2015$.

Saragih, F.J. 2009. Pengaruh Media Tanam dan Pemberian Mikoriza Vesikula Arbuskula (MVA) Terhadap Pertumbuhan Stump Mata Tidur Karet (Havea brasiliessis Muell.Arg.) [Skripsi]. Universitas Sumatra Utara, Medan.

Soesanto L. 2008. Pengantar Pengendalian Hayati Penyakit Tanaman. PT Raja Grafindo Persada, Jakarta. Sudir, A Nasution, Santoso, dan B Nuryanto. 2014. Penyakit blas Pyricularia grisea pada tanaman padi dan strategi pengendaliannya. Iptek Tanaman Pangan. 9(2): 85-96.

Suganda, T. 2016. Pentingnya penelitian tentang penaksiran kehilangan hasil akibat organisme pengganggu tanaman. [Abstract]. Seminar Plant Protection Day dan Seminar Nasional II, 20 Oktober 2016. Universitas Padjadjaran.

Supriadi. 2006. Analisis resiko agen hayati untuk pengendalian patogen tanaman. J. Litbang Pertanian 25(3):75-80.

Teale, W.D., I.A. Paponov, and K. Palme. 2006. Auxin in action: signalling, transport and the control of plant growth and development. Nat. Rev. Mol. Cell Biol. 7: 847859.

Untung, 2006. Pengantar Pengelolaan Hama Terpadu, Gajah Mada University Press. Yoyakarta.

Vasudevan, P., S. Kavitha, V.B. Priyadarisini, L. Babujee, and S.S. Gnanamanickam. 2002. Biological control of rice diseases, pp. 11-32. In S.S. Gnanamanickam (Eds.). Biological Control of Crop Diseases. Marcel Dekker, New York. Swain, M.R., S.K. Naskar, and R.C. Ray. 2006. Indole-3-acetic acid production and effect on sprouting of yam (Dioscorea rotundata L.) minisetts by Bacillus subtilis isolated from culturable cowdung microflora. Polish J. Microbio. 56(2): 103-110.

Wang, X, S Lee, J Wang, J Ma, T Bianco, and Y Jia. 2014. Current advances on genetic resistance to rice blast disease. Chapter 7 in Rice-Germplam, Genetics and Improvement (W Yan and $\mathrm{J}$ Bao, eds.). Available online at: http://www.intechopen.com/books/rice-germplasm-genetics-and-improvement/ 
Dian Eka Kusumawati \& Istiqomah, 2020. Potensi Agensia Hayati Dalam Menekan Laju Serangan Penyakit Blas (Pyricularia Oryzae) Pada Tanaman Padi. Journal Viabel Pertanian. (2020), 14(2)1-13

current-advances-on-genetic-resistance-to-rice-blast-disease. (diakses 2 September 2020).

Winarsih, S. dan Syafrudin. 2001. Pengaruh pemberian Trichoderma viride dan sekam padi terhadap penyakit rebah kecambah di persemaian cabai. J. Ilmu Pertanian Indonesia 3(1):49-55.

Yuen GY, Schroth MN. 1986. Interactions of Pseudomonas fluorescens strain E6 with ornamental plant and its effect on the composition of root-colonizing microflora. Phytopathol 76: 176-180. 